\title{
A new troglomorphic species of Austrochthonius (Pseudoscorpiones: Chthoniidae) from Australia, with remarks on Chthonius caecus
}

\author{
Mark S. Harvey' and Lee G. Mould ${ }^{2}$ \\ 1 Department of Terrestrial Invertebrates, Western Australian Museum, \\ Locked Bag 49, Welshpool DC, Western Australia 6986, Australia. \\ E-mail: mark.harvey@museum.wagovau \\ 2 Biota Environmental Sciences Pty Ltd, PO Box 176 \\ North Perth, Western Australia 6906, Australia. \\ E-mail: leegbiotanet.au
}

\begin{abstract}
A new species of the chthoniid genus Austrochthonius Chamberlin is described and named from the Ludlow region of southern Western Australia. Austrochthonius strigosus sp. nov. exhibits some strong troglomorphic adaptations such as eye loss, elongate pedipalps and pallid colouration. Chthonius caecus Tullgren, 1909, a junior homonym, and its replacement name Sathrochthonius tulgreni Chamberlin, 1962, are transferred to Austrochthonius. A new replacement name, Austrochthonius muchmorei, is provided, as $A$. tullgreni is a junior secondary homonym of $A$. tullgreni (Beier, 1931)
\end{abstract}

\section{INTRODUCTION}

The chthoniid genus Austrochthonius possesses a typical Gondwanan distribution with eight species recorded from southern South America, three species from New Zealand, three species from Australia, one species from the Iles Crozet, and one species from South Africa (Harvey 1991a, 1991c Judson 2001). The Australian fauna consist of Austrochthonius australis Hoff from southern Australia and two troglobitic species from caves in the Naracoorte region, South Australia (A. cavicola Beier) and Cape Range peninsula, Western Australia (A. easti Harvey). Kennedy (1990) presented a redescription of $A$. australis based upon large quantities of material from south-eastern Australia and noted that the Western Australian specimens attributed to A. australis by Beier (1966a) were sufficiently different from $A$. australis that they represented a distinct species. An additional species from the Kimberley region of Western Australia was reported by Harvey (1991b) but it currently remains undescribed.

Epigean members of Austrochthonius in Australia can be quite common in leaf litter and soil, but the troglobitic species are relatively uncommon with just a few specimens collected. Whilst considerable work is needed to unravel the sustematic relationships of the genus within Australia, we are here describing a new troglomorphic species of the genus that has been recovered from subterranean sampling undertaken in the Ludlow area near Busselton, south-western Australia. Although only a single male has been collected, it is sufficiently distinct from all other species of the genus that we have prepared a systematic description to formally record this unusual species in the scientific literature. We also comment on the species first named as Chthonius caecus Tullgren from southwestern Australia (Tullgren 1909) which has since been transferred to the genus Sathrochthonius Chamberlin and renamed $S$. tullgreni (Chamberlin, 1962). We suggest that this species is in fact a species of the genus Austrochthonius.

\section{MATERIAL AND METHODS}

The material utilized in the present study is lodged in the Western Australian Museum, Perth (WAM). Terminology and mensuration mostly follows Chamberlin (1931), with the exception of the nomenclature of the pedipalps, legs and with some minor modifications to the terminology of the trichobothria (Harvey 1992). In particular, it should be noted that the terminology for the trichobothria used by Harvey (1992) differs slightly from that used by other workers.

The specimen was examined by preparing a temporary slide mounts by immersing the specimen in $75 \%$ lactic acid at room temperature for several days, and mounting it on a microscope slide with $10 \mathrm{~mm}$ coverslips supported by small sections of $0.25 \mathrm{~mm}$ or $0.50 \mathrm{~mm}$ diameter nylon fishing line. It was examined with an Olympus $\mathrm{BH}-2$ compound microscope and illustrated with the aid of a drawing tube. Measurements were taken at the highest possible magnification using an ocular 
graticule. After study the specimen was returned to $75 \%$ ethanol with the dissected portions placed in $12 \times 3 \mathrm{~mm}$ glass genitalia microvials (BioQuip Products, Inc.).

\section{SYSTEMATICS}

\section{Family Chthoniidae Daday}

\section{Subfamily Chthoniinae Daday}

\section{Genus Austrochthonius Chamberlin}

Austrochthonius Chamberlin, 1929: 68. Type species: Chthonius chilensis Chamberlin, 1923, by original designation.

Paraustrochthonius Beier, 1931: 52 (synonymised by Beier, 1976: 203). Type species: Paraustrochthonius tullgreni Beier, 1931, by original designation.

Cecoditha Mello-Leitão, 1939: 115-116 (synonymised by Judson, 2001: 142). Type species: Cecoditha parva Mello-Leitão, 1939, by original designation.

\section{Remarks}

Austrochthonius belongs to a group of genera characterised by the presence of coxal spines only on coxa II and that lack one or more enlarged spinelike setae on the interno-basal margin of the chelal hand. Defined in this way, this group currently includes nine genera: Austrochthonius, Chiliochthonius Vitali-di Castri, Drepanochthonius Beier, Francochthonius Vitali-di Castri, Maorichthonius Chamberlin, Malcolmochthonius Benedict, Mexichthonius Muchmore, Mundochthonius Chamberlin and Tyrannochthoniella Beier. The African genus Congochthonius Beier was also attributed by Muchmore (2001) to a group containing some of these genera but the affinities of this unusual genus appear to lie with Sathrochthonius Chamberlin and Sathrochthoniella Beier due to a small suite of morphological features of which the most prominent is the sub-basal position of trichobothria $i b$ and is $b$.

Six genera of the Austrochthonius group occur in the southern hemisphere, whereas three genera occur in the northern hemisphere. Austrochthonius species are found on all of the southern continents (Harvey 1996), as well as the lles Crozet (Vitali-di Castri 1968); species of Chiliochthonius, Drepanochthonius and Francochthonius are restricted to Chile (Beier 1964a; Vitali-di Castri 1976); and the genera Maorichthonius and Tyrannochthoniella are endemic to New Zealand (Beier 1976). The three Laurasian genera, Mundochthonius, Malcolmochthonius and Mexichthonius, occur in North America, whilst species of
Mundochthonius have also been recorded from Europe and East Asia (summarized by Harvey 1991a), with subsequent species recently named by Kim and Hong (1994), Muchmore (1996), Sakayori (2002), Dashadamirov (2005) and Zaragoza and Harvey (2006). The relationships and status of some of these genera is doubtful and some rationalisation may be expected in the future.

\section{Austrochthonius strigosus sp. nov.} Figures 1-5

\section{Material Examined}

\section{Holotype}

§., Ludlow region (site $\mathrm{LDMB} 2,33.58921503^{\circ} \mathrm{S}$ $\left.115.4904651^{\circ} \mathrm{E}\right), 3^{\circ} 35^{\prime} 21^{\prime \prime} \mathrm{S}, 115^{\circ} 29^{\prime} 26^{\prime \prime} \mathrm{E}$, Western Australia, Australia, 18 November 2004, from borehole at approximately $5 \mathrm{~m}$ depth, L. Mould and D. Kamien (WAM T65550).

\section{Diagnosis}

Austrochthonius strigosus differs from all previously named species of the genus by the elongate pedipalpal chela which is 6.35 times longer than broad in the holotype male, but less than 5.4 times longer than broad in other species (Table 1).

\section{Description}

Adult male (holotype, WAM T65550): Colour generally pale yellow-brown, legs slightly paler than body.

Chelicera: with 5 setae on hand and 1 medial seta on movable finger (Figure 3); fixed finger with 5 small teeth, of approximately same size; movable finger slightly shorter than hand, with 4 small teeth and 2 extremely small teeth; blades of the flagellum not clearly visible; galea a short rounded nubbin.

Pedipalp: trochanter 1.73 , femur 4.95 , patella 1.89 , chela 6.35 , chelal hand 2.17 times longer than broad; movable chelal finger 1.90 times longer than hand; fixed chelal finger with 69 teeth, moveable chelal finger with 55 teeth, all teeth closely spaced and either gently rounded or slightly truncate (Figure 1); fixed chelal finger and hand with 8 trichobothria, movable chelal finger with 4 trichobothria (Figures $1,2) ; i b$ and isb situated sub-medially on dorsum of chelal hand; $e b$ and $e s b$ situated sub-laterally at base of chelal fingers; xs situated slightly distal to et near tip of fixed finger, each hair shorter than those of other trichobothria; $b$ situated slightly closer to $t$ than to $s b$; $s b$ closer to $b$ than to $s t$, venom apparatus absent.

Carapace: 1.05 times longer than broad; without eyes; anterior margin finely denticulate with very distinct and strongly toothed epistome (Figure 5); with 18 setae arranged $6: 4: 4: 2: 2$; the pre-ocular seta about $50 \%$ length of other setae in anterior row; 
Table 1 Species of Austrochthonius, with distributions and pedipalpal chela ratios.

\begin{tabular}{|c|c|c|c|}
\hline Species & Distribution & $\begin{array}{l}\text { Ratio of pedipalpal } \\
\text { chela length/width }\end{array}$ & Reference \\
\hline A. argentinae Hoff & South America & 4.81 (female) & (Hoff, 1950) \\
\hline A. australis Hoff & Australia & 4.07 (female) & (Hoff, 1951) \\
\hline A. bolivianus Beier & South America & 4.2 (adult) & $\begin{array}{l}\text { (Beler, 1966a) } \\
\text { (Beier, 1932) }\end{array}$ \\
\hline A. cavicola Beier & Australia & 5.2 (male) & (Beier, 1967a) \\
\hline A. chilensis chilensis (Chamberlin) & South America & 4.30 (female) & (Chamberlin, 1923) \\
\hline A. chilensis magalhanicus Beier & South America & not stated & (Beier, 1964a) \\
\hline A. chilensis transversus Beier & South America & $\begin{array}{l}5.4 \text { (male) } \\
4.8 \text { (female) }\end{array}$ & (Beier, 1964b) \\
\hline A. easti Harvey & Australia & 4.17 (male) & (Harvey, 1991c) \\
\hline A. iguazuensis Vitali-di Castri & South America & 2.82 (female) & (Vitali-di Castri, 1975) \\
\hline A insularis Vitali-di Castri & Îles Crozet & 4.4 (female) & (Vitali-di Castri, 1968) \\
\hline A. mordax Beier & New Zealand & $\begin{array}{l}5.2-5.3 \text { (male) } \\
4.5 \text { (female) }\end{array}$ & (Beier, 1967b) \\
\hline A paraguayensis Vitali-di Castri & South America & 3.54 (male) & (Vitali-di Castri, 1975) \\
\hline A. parvus (Mello-Leitāo) & South America & 5.3 (male) & (Judson, 2001) \\
\hline A. persimilis Beier & South America & 4.0 (female) & (Beier, 1964a) \\
\hline A. rapax Beier & New Zealand & 4.2 & (Beier, 1976) \\
\hline A. semiserratus Beier & South America & 4.64 (female) & (calculated from Beier, 1930, fig. 11a) \\
\hline A. strigosus sp. nov. & Australia & 6.35 (male) & this paper \\
\hline A tullgreni (Beier) & South Africa & 4.6 (adult) & (Beier, 1931) \\
\hline A. zealandicus zealandicus Beier & New Zealand & $\begin{array}{l}4.9-5.2 \text { (male) } \\
4.1-4.4 \text { (female) }\end{array}$ & $\begin{array}{l}\text { (Beier, 1967b) } \\
\text { (Beier, 1966b) }\end{array}$ \\
\hline A. zealandicus obscurus Beier & New Zealand & 4.0 (adult) & (Beier, 1966b) \\
\hline
\end{tabular}

with 3 pairs of lyrifissures, one pair situated anteromedially, the second pair situated interno-lateral to the "ocular" region, and the third pair situated exterior to the sole pair of setae of the posterior row.

Coxal region: coxal chaetotaxy: $2+3: 3+2 m: 4: 5: 5$ (Figure 4); manducatory process with 2 acuminate distal setae, about equal in length to each other; pedipalpal coxa without dorsal setae; intercoxal tubercle absent; coxa I without apical projection, but with 2 small microsetae $(\mathrm{m})$ situated on distal margin; other setae on coxa I situated near trochanteral foramen (Figure 4); coxal spines present only on coxa II, 6 (left coxa) or 7 (right coxa) bipinnate spines present, bases not contiguous (Figure 4).

Legs: femurtpatella IV 2.84 times longer than deep; heterotarsate; arolium slightly shorter than claws, claws simple.

Abdomen: tergites and sternites undivided; tergal chaetotaxy, 4: 4: 4: 4:5:6:6:6:6:6:6:0; sternal chaetotaxy, 10: (1) 26 (1): (2) $7[4+4]$ (2): 9: 8: 8: 8: 8: 8: -: 2. All setae bordering sternite III acuminate. Genitalia of male not studied in detail (due to poor preservation), but 4 pairs of stout glandular setae present within genital atrium. Pleural membrane evenly plicate.

\section{Dimensions ( $\mathrm{mm}$ )}

Holotype male (WAM T65550): Body length 1.184. Pedipalps: trochanter $0.176 / 0.102$, femur
$0.505 / 0.102$, patella $0.217 / 0.115$, chela $0.768 / 0.121$, hand length 0.262 , movable finger length 0.499 . Chelicera $0.352 / 0.169$, movable finger length 0.195 . Carapace $0.403 / 0.384$. Leg I: femur $0.280 / 0.054$, patella $0.131 / 0.051$, tibia $0.150 / 0.041$, tarsus $0.438 /$ 0.141. Leg IV: femur + patella $0.417 / 0.147$, tibia $0.301 / 0.069$, metatarsus $0.146 / 0.052$, tarsus missing.

\section{Remarks}

The single specimen was taken from a bore at a depth of approximately $5 \mathrm{~m}$ during sampling targeting stygofauna in the region. The pseudoscorpion was collected in a sample raised to the surface using a modified plankton net and collection jar, lowered into a borehole through a $50 \mathrm{~mm}$ diameter piezometer (a non-pumping well, generally of small diameter, for measuring the elevation of a water table or for other groundwater monitoring) within limestone sediments in the Ludlow region. Additional wells were sampled in the area by the junior author and, despite several sampling attempts in the region, no further specimens were obtained. Thus, at present, A. strigosus is known only from a single karst location situated in south-western Australia. The type locality comprises open woodland composed of Tuart (Eucalyptus gomphocephala, Myrtaceae) and Peppermint (Agonis flexuosa, Myrtaceae) with an understorey dominated by weeds including Arum Lily (Zantedeschia aethiopica, Araceae) and introduced grasses on a floor of dense leaf litter and sandy soil. 


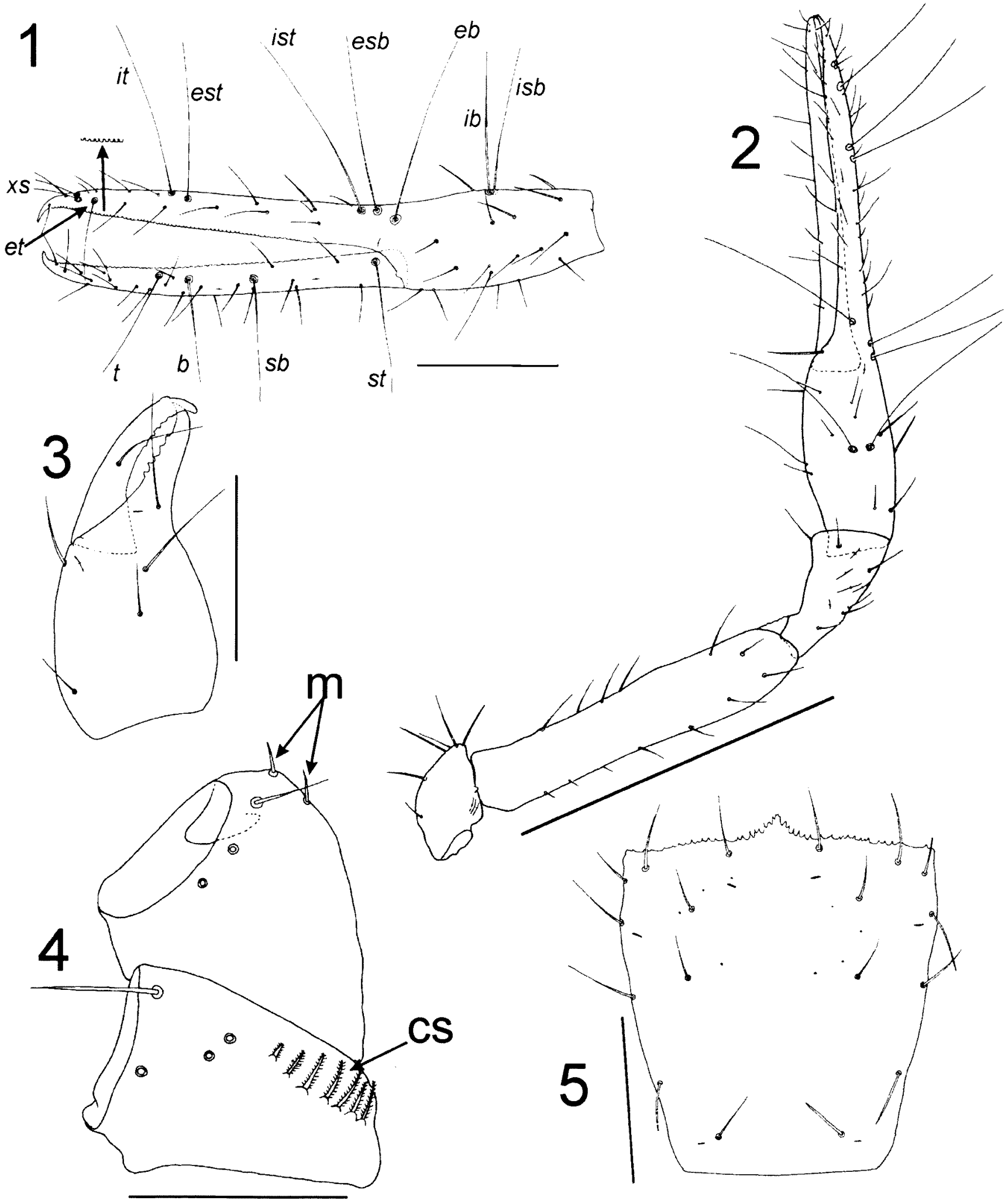

Figures 1-4 Austrochthonius strigosus sp. nov., holotype male. 1, left chela, lateral view. 2, right pedipalp, dorsal view. 3, left chelicera, dorsal view. 4, right coxae I and II (abbreviations: $c a=$ coxal spines; $m=$ microsetae). 5 , carapace, dorsal view. Scale lines $=0.10 \mathrm{~mm}$ (Figure 4), $0.20 \mathrm{~mm}$ (Figures $1,3,5), 0.50 \mathrm{~mm}$ (Figure 2). 
The holotype is slightly macerated and covered in a fine sediment which is consistent with the specimen spending some time after death in the water within the bore, or at least on the surface of the water column. It is lacking several legs and the distal segments are missing on others.

On the basis of the total lack of eyes (Figure 5) and the strongly elongated pedipalpal segments (Figures 1, 2), A. strigosus is clearly the most troglomorphic species thus far recognized in the genus. The only other cave-dwelling species, $A$. cavicola from the Naracoorte Caves, South Australia and A. easti from the Cape Range Caves, Western Australia, possess less elongate pedipalpal segments. Although both $A$. strigosus and $A$. cavicola completely lack eyes (Beier, 1968), A. easti has a single pair of small anterior eyes (Harvey, 1991c). All epigean species of the genus, with the exception of the blind A. iguazuensis, either possess two pairs of eyes or a single pair of eyes.

Austrochthonius strigosus satisfies the criteria discussed by Harvey (2002) to be considered as a short-range endemic species. It has an exceedingly small distribution and occurs in such a specialised habitat - karst within the Ludlow region - that the total area of occupancy is likely to be minimal.

\section{Etymology}

The specific epithet denotes the slender pedipalpal chela (strigosus, Latin, lean, thin).

\section{A ustrochthonius muchmorei nom. nov.}

Chthonius caecus Tullgren, 1909: 414-415, figure 3 ljunior primary homonym of Chthonius coecus Packard, 1884 and Chthonius caecus Simon, 1885].

Mundochthonius (?) caecus (Tullgren): Beier 1932: 38; Roewer 1937: 238.

Mundochthonius caecus (Tullgren): Nicholls 1933: 111; Chamberlin, 1934: 3; Weidner 1959: 115.

Sathrochthonius tullgreni Chamberlin, 1962: 306307 [replacement name for Chthonius caecus Tullgren; junior secondary homonym of Austrochthonius tullgreni (Beier, 1931)|; Harvey 1981: 241; Harvey 1985: 140-141; Harvey 1991a: 202.

Sathrochthonius (?) tullgreni Chamberlin: Beier, 1966a: 276; Muchmore 1982: 158.

\section{Remarks}

Tullgren (1909) described Chthonius caecus based upon a single male collected from Brunswick (a small town to the south of Perth that is now called Brunswick Junction, $33^{\circ} 15 \mathrm{~S}, 11550 \mathrm{\prime}$ ) during the Michaelsen and Hartmeyer Expedition on 7 October
1905. The specimen was doubtfully transferred to the genus Mundochthonius by Beier (1932: 38) who reported that the specimen was lost ("Type verloren gegangen"). Weidner (1959) reported that the specimen was lost in July 1930 from the Zoologisches Institut und Zoologisches Museum, Universität Hamburg Germany, which has been recently confirmed for us by Dr Hieronymus Dastych (in litt., 17 May 2006). Chamberlin (1962) speculated on the identity of $C$. caecus and tentatively transferred it to his newly formed genus Sathrochthonius, also noting that it was a junior primary homonym of both $C$. coecus Packard, 1884 and $C$. caecus Simon, 1885 (International Commission on Zoological Nomenclature, 1999, Article 58). To resolve the homonymy, Chamberlin (1962) provided the replacement name $S$. tullgreni. Beier (1966a) and Muchmore (1982) doubted that Chamberlin's generic placement of this species was correct, the former by including a question mark after the generic name [Sathrochthonius (?) tullgreni], and the latter by stating that "there is no way to determine the identity of this species until topotypic material ... is studied."

The speculation that Tullgren's specimen was a member of the genus Sathrochthonius is here believed to be erroneous, and we suggest that it is better placed in the genus Austrochthonius. The original description by Tullgren (1909) clearly illustrates a specimen with straight chelal fingers (when viewed dorsally). The chelal fingers of Sathrochthonius species are gently but unquestionably curved (e.g., Chamberlin 1962, fig. 1b; Muchmore 1982, fig. 2), whereas species of Austrochthonius, as well as many other chthoniids, possess straight or nearly straight chelal fingers. Furthermore, whilst members of Austrochthonius are quite common throughout south-western Australia, species of Sathrochthonius are very rare. Indeed, the only records of Sathrochthonius from the region are of an unnamed species from Quininup (34 $28^{\prime} \mathrm{S}, 116^{\circ} 15^{\prime} \mathrm{E}$ ) (WAM 80/1373), West Cape Howe (3508'S, 117 36'E) (WAM 89/363-364) and Warren National Park near Pemberton (34 $27^{\prime} \mathrm{S}$, $116^{\circ} 02^{\prime} \mathrm{E}$ ) (WAM 80/1151-1153). The only other chthonioids in the region are Lagynochthonius australicus (Beier) which occurs in high rainfall regions along the south coast of Western Australia, and several species of Pseudotyrannochthonius which are found in a variety of disjunct locations in the area (Harvey, unpublished data). The description of C. caecus by Tullgren (1909) clearly demonstrates that it does not belong to either of these genera.

Based upon this reasoning, we here transfer Chthonius caecus Tullgren and the replacement name Sathrochthonius tullgreni Chamberlin to Austrochthonius. Unfortunately this species then becomes a junior secondary homonym of Austro- 
chthonius tullgreni (Beier, 1931) from South Africa. Therefore a replacement name, $A$. muchmorei, is here proposed.

It is beyond the scope of this paper to provide a complete description of $A$. muchmorei as there is more than one species of Austrochthonius occurring in leaf litter and soil within south-western Australia (Harvey, unpublished data) and there are considerable difficulties in determining suitable species level boundaries amongst this assemblage.

\section{Etymology}

This species is named for William B. Muchmore, in recognition of his outstanding contribution to pseudoscorpion systematics over a 40-year period. He also suggested that $S$. tullgreni may be misplaced in Sathrochthonius.

\section{ACKNOWLEDGEMENTS}

We wish to thank Cable Sands (WA) Pty Ltd for access to the study site and Biota Environmental Sciences Pty Ltd for their resources and support. Dr H. Dastych (Zoologisches Museum und Zoologisches Museum, Universität Hamburg) kindly provided information on the holotype of Chthonius caecus, and two anonymous referees made valuable comments on a draft of the manuscript.

\section{REFERENCES}

Beier, M. (1930). Alcuni Pseudoscorpioni esotici raccolti dal Prof. F. Silvestri. Bollettino del Laboratorio di Zoologia Generale e Agraria del R. Istituto Superiore Agrario in Portici 23: 197-209.

Beier, M. (1931). Zur Kenntnis der Chthoniiden (Pseudoskorpione). Zoologischer Anzeiger 93: 49-56.

Beier, M. (1932). Pseudoscorpionidea I. Subord. Chthoniinea et Neobisiinea. Tierreich 57: i-xx, 1-258.

Beier, M. (1964a). Die Pseudoscorpioniden-Fauna Chiles. Annalen des Naturhistorischen Museums in Wien 67: 307-375

Beier, M. (1964b). The zoological results of Gy. Topál's collectings in South Argentina. 15. Pseudoscorpionidea. Annales Historico-Naturales Musei Nationalis Hungarici 56: 487-500.

Beier, M. (1966a). On the Pseudoscorpionidea of Australia. Australian Journal of Zoology 14: 275-303.

Beier, M. (1966b). Zur Kenntnis der PseudoscorpionidenFauna Neu-Seelands. Pacific Insects 8: 363-379.

Beier, M. (1967a). Some Pseudoscorpionidea from Australia, chiefly from caves. Australian Zoologist 14: 199-205.

Beier, M. (1967b). Contributions to the knowledge of the Pseudoscorpionidea from New Zealand. Records of the Dominion Museum 5: 277-303

Beier, M. (1968). Some cave-dwelling Pseudoscorpionidea from Australia and New Caledonia. Records of the South Australian Museum 15: 757-765.
Beier, M. (1976). The pseudoscorpions of New Zealand, Norfolk and Lord Howe. New Zealand Journal of Zoology 3: 199-246.

Chamberlin, J.C. (1923). On two species of pseudoscorpion from Chile with a note in [sic] one from Sumatra. Revista Chilena de Historia Natural 27: 185-192.

Chamberlin, J.C. (1929). A synoptic classification of the false scorpions or chela-spinners, with a report on a cosmopolitan collection of the same. Part 1. The Heterosphyronida (Chthoniidae) (ArachnidaChelonethida). Annals and Magazine of Natural History (10) 4: 50-80.

Chamberlin, J.C. (1931). The arachnid order Chelonethida. Stanford University Publications, Biological Sciences 7(1): 1-284.

Chamberlin, J.C. (1934). Check list of the false scorpions of Oceania. Occasional Papers of the Bernice P. Bishop Museum 10(22): 1-14.

Chamberlin, J.C. (1962). New and little-known false scorpions, principally from caves, belonging to the families Chthoniidae and Neobisiidae (Arachnida, Chelonethida). Bulletin of the American Museum of Natural History 123: 303-352.

Dashdamirov, S. (2005). Pseudoscorpions from the mountains of northern Pakistan (Arachnida: Pseudoscorpiones). Arthropoda Selecta 13: 225-261.

Harvey, M.S. (1981). A checklist of the Australian Pseudoscorpionida. Bulletin of the British Arachnological Society 5: 237-252.

Harvey, M.S. (1985). Pseudoscorpionida. In D.W. Walton (ed.), Zoological Catalogue of Australia, vol. 3: 126155. Australian Government Publishing Service: Canberra.

Harvey, M.S. (1991a). Catalogue of the Pseudoscorpionida. Manchester University Press: Manchester.

Harvey, M.S. (1991b). The Pseudoscorpionida and Schizomida of the Kimberley Rainforests. In N.L. McKenzie, R.B. Johnston and P.G. Kendrick (eds), Kimberley Rainforests, pp: 265-268. Surrey Beatty \& Sons: Chipping Norton.

Harvey, M.S. (1991c). The cavernicolous pseudoscorpions (Chelicerata: Pseudoscorpionida) of Cape Range, Western Australia. Records of the Western Australian Museum 15: 487-502.

Harvey, M.S. (1992). The phylogeny and classification of the Pseudoscorpionida (Chelicerata: Arachnida). Invertebrate Taxonomy 6: 1373-1435.

Harvey, M.S. (1996). The biogeography of Gondwanan pseudoscorpions (Arachnida). Revue Suisse de Zoologie, hors série 1: 255-264.

Harvey, M.S. (2002). Short-range endemism in the Australian fauna: some examples from non-marine environments. Invertebrate Systematics 16: 555-570.

Hoff, C.C. (1950). Pseudoescorpionidos nuevos o poco conocidos de la Argentina (Arachnida, Pseudoscorpionida). Arthropoda, Buenos Aires 1: 225-237.

Hoff, C.C. (1951). New species and records of chthoniid pseudoscorpions. American Museum Novitates 1483: $1-13$.

International Commission on Zoological Nomenclature 
(1999). International Code of Zoological Nomenclature, fourth edition. International Trust for Zoological Nomenclature: London.

Judson, M.L.I. (2001). Synonymy of Cecoditha (Cecodithinae) with Austrochthonius (Chthoninae) (Chelonethi, Chthoniidae). Journal of Arachnology 29 : $141-145$.

Kennedy, C.M.A. (1990). Redescription of Austrochthonius australis Hoff (Chthonidae: Pseudoscorpionida). Proceedings of the Linnean Society of New South Wales 111: 233-240.

Kim, T.H. and Hong, Y. (1994). Two new species of Chthoniidae (Arachnida: Pseudoscorpiones) from Korea. Korean Journal of Systematic Zoology 10: 4753.

Mello-Leitão, C. (1939). Pseudoscorpionidos de Argentina. Notas del Museo de La Plata 4: 115-122.

Muchmore, W.B. (1982). A new cavernicolous Sathrochthonius from Australia (Pseudoscorpionida: Chthoniidae). Pacific Insects 24: 156-158.

Muchmore, W.B. (1996). A new Mundochthonius from the Dominican Republic (Pseudoscorpionida: Chthoniidae). Insecta Mundi 10: 104.

Muchmore, W.B. (2001). An unusual new species of Mundochthonius from a cave in Colorado, with comments on Mundochthonius montanus (Pseudoscorpiones, Chthoniidae). Journal of Arachnology 29: 135-140.

Nicholls, G.E. (1933). The composition and biogeographical relations of the fauna of Western Australia. In A.B. Walkom, (ed.), Report of the Twenty-First Meeting of the Australian and New Zealand Association for the Advancement of Science, Sydney Meeting, August, 1932, pp: 93-138. Australian and New Zealand Association for the Advancement of Science: Sydney.

Packard, A.S. (1884). New cave arachnids. American Naturalist 18: 202-204.

Roewer, C.F. (1936, 1937, 1940). Chelonethi oder Pseudoskorpione. In H.G. Bronns (ed.), Klassen und Ordnungen des Tierreichs, vol. 5(IV)(6)(1): 1-534. Akademische Verlagsgesellschaft M.B.H. Leipzig.
Sakayori, H. (2002). Two new species of the family Chthoniidae from Kyushu, in western Japan (Arachnida: Pseudoscorpionida). Edaphologia 69: 18.

Simon, E. (1885). Arachnides recueillies dans la vallée de Tempé et sur le mont Ossa (Thessalie) par M. de Dr J. Stussiner (de Laibach). Annales de la Société Entomologique de France (6) 5: 209-217.

Tullgren, A. (1909). Chelonethi. In Michaelsen, W. and Hartmeyer, R. (eds), Fauna Sudwest-Australiens, vol. 2: 411-415. Gustav Fischer: Jena.

Vitali-di Castri, V. (1968). Austrochthonius insularis, nouvelle espece de pseudoscorpions de l'Archipel de Crozet (Heterosphyronida, Chthoniidae). Bulletin du Muséum National d'Histoire Naturelle, Paris (2) 40 : $141-148$

Vitali-di Castri, V. (1975). Nuevos Austrochthonius sudamericanos (Pseudoscorpionida, Chthoniidae). Phvsis, Buenos Aires 34: 117-127.

Vitali-di Castri, V. (1976). Deux nouveaux genres de Chthoniidae du Chili: Chiliochthonius et Francochthonius (Arachnida, Pseudoscorpionida). Bulletin du Muséum National d'Histoire Naturelle, Paris (3) 334: $1277-1291$.

Weidner, H. (1959). Die Entomologischen Sammlungen des Zoologischen Staatsinstituts und Zoologischen Museums Hamburg. I. Teil. Pararthropoda und Chelicerata I. Mitteilungen aus dem Hamburgischen Zoologischen Museum und Institute 57: 89-142.

Zaragoza, J.A. and Harvey, M.S. (2006). The first record of the genus Mundochthonius Chamberlin (Pseudoscorpiones: Chthoniidae) from Spain: Mundochthonius gallaecicus sp. nov. Revista Ibérica de Aracnología 12: 17-23.

Manuscript received 19 May 2006; accoted 14 hune 2006 


\section{Guide to Authors}

\section{Subject Matter:}

Reviews, observations and results of reseatrch into all branches of natural science and human studies will be considered for publication. However. emphasis is placed on studies pertaining to Westem Australia. Longer papers will be considered for publication as a Supplement to the Records of the Western Australian Muselum. Short communications should not normally exceed three typed pages and this category of paper is intended to accommodate observations, results or new records of significance. that otherwise might not get into the literature, or for which there is a particular urgency for publication. All material must be original and not have been published elsewhere

\section{Presentation:}

Authors are advised fo follow the layout and style in the most recent issue of the Records of the Westem Australian Muscum including headings. tables, illustrations and references

The title should be concise. informative and contain key words necessary for retrieval by modern searching techniques. An abridged title not exceeding 50 letter spaces) should be included for use as a running head

An abstract must be given in full length papers but not short communications. summarizing the scope of the work and principal findings. It should normally not exceed $2 \%$ of the paper and should be suitable for reprinting in reference periodicals.

The International System of units should be used.

Numbers should be spelled out from one 10 nine in descriptive text: figures used for 10 or more. For associated groups, figures should be used consistently, e.g. 5 to 10 , not five to 10

Spelling should follow the Conctse oxford Dictionam.

Systematic papers must conform with the International Codes of Botanical and Zoological Nomenclature and as far as possible. With their recommendations.

Synonymies should be given in the short form (taxon. author. date. page) and the full reference cited at the end of the paper. All citations, including those associated with scientific names, must be included in the references

\section{Manuscripts:}

The original and two copies of manuscripts and figures should be submitted to the Editor, c/ Publications Department. Western Australian Museum. Locked Bag 49. Welshpool DC. Western Australia 6986. They must be in double-spaced typescript on A4 sheets. All margins should be at least $30 \mathrm{~mm}$ wide. Tables plus heading and legends to illustrations should be typed on separate pages. The desired position for insertion of tables and illustrations in the text should be indicated in pencil. Tables should be numbered consecutively, have headings which make them understandable without reference to the text, and be referred to in the text.

High quality illustrations are required to size $(16.8 \mathrm{~cm} \times 25.2 \mathrm{~cm})$ or no larger than $32 \mathrm{~cm} \times 40$ $\mathrm{cm}$ with sans serif lettering suitable for reduction to size. Photographs must be good quality black and white prints, not exceeding $16.8 \mathrm{~cm} \times 25.2 \mathrm{~cm}$. Scale must be indicated on illustrations. All maps, line drawings, photographs and graphs, should be numbered in sequence and referred to as Figure/s in the text and captions. Each must have a brief, fully explanatory caption. On acceptance a computer disk containing all corrections should be sent with amended manuscript. The disk should be marked with program (e.g. Word, WordPerfect, etc).

In papers dealing with historical subjects references may be cited as footnotes. In all other papers references must be cited in the text by author and date and all must be listed alphabetically at the end of the paper. The names of journals are to be given in full.

\section{Processing:}

Papers and short communications are reviewed by at least two referees and acceptance or rejection is then decided by the editor

The senior author is sent one set of page proofs which must be retumed promptly.

The senior author will receive fifty free offprints of the paper. Additional offprints can be ordered at page proof stage. 


\section{Records of the Western Australian Museum Volume 23 Part 22006}

\section{CONTENTS}

\section{R.E. Johnstone}

The birds of Gag Island, Western Papuan islands, Indonesia

\section{David L. Morgan and Howard S. Gill}

Osteology of the first dorsal fin in two terapontid fishes, Leiopotherapon unicolor (Günther, 1859) and Amniataba caudavittata (Richardson, 1845), from Western Australia: evidence for hybridisation?

Volker W. Framenau

The wolf spider genus Venatrix Roewer: new species, synonymies and generic transfers (Araneae, Lycosidae)

\section{Mark S. Harvey}

New species and records of the pseudoscorpion family Menthidae (Pseudoscorpiones)

\section{Brian Morton}

The functional morphology of Penicillus philippinensis (Anomalodesmata: Clavagelloidea: Penicillidae) and the evolution of an unique muscular system in the Bivalvia

Gregory D. Edgecombe

A troglobitic cryptopid centipede (Chilopoda: Scolopendromorpha) from western Queensland

\section{Mark S. Harvey, Frantisek Štáhlavský and Pieter D. Theron}

The distribution of Eukoenenia mirabilis (Palpigradi: Eukoeneniidae): a widespread tramp

Mark S. Harvey and Lee G. Mould

A new troglomorphic species of Austrochthonius (Pseudoscorpiones: Chthoniidae) from Australia, with remarks on Chthonius caecus 